\title{
TGF $\beta$ Affects Collagen Cross-Linking Independent of Chondrocyte Phenotype but Strongly Depending on Physical Environment
}

\author{
YVONNE MARIA BASTIAANSEN-JENNISKENS, M.Sc., ${ }^{1,2}$ WENDY KOEVOET, B.Sc., ${ }^{3}$ \\ ANTON C.W. DE BART, B.Sc., ${ }^{2}$ ANNE-MARIE ZUURMOND, Ph.D., ${ }^{2}$ RUUD A. BANK, Ph.D., ${ }^{2,4}$ \\ JAN A.N. VERHAAR, M.D., Ph.D., JEROEN DeGROOT, Ph.D., ${ }^{2}$ \\ and GERJO J.V.M. VAN OSCH, Ph.D.,
}

\begin{abstract}
Transforming growth factor beta (TGF $\beta$ ) is often used in cartilage tissue engineering to increase matrix formation by cells with various phenotypes. However, adverse effects of TGF $\beta$, such as extensive crosslinking in cultured fibroblasts, have also been reported. Our goal was to study effects of TGF $\beta$ on collagen cross-linking and evaluating the role of cellular phenotype and physical environment. We therefore used four different cell populations in two very different physical environments: primary and expanded chondrocytes and fibroblasts embedded in alginate gel and attached to tissue culture plastic. Matrix production, collagen cross-linking, and $\alpha$-smooth muscle actin ( $\alpha$ SMA) were analyzed during 4 weeks with or without $2.5 \mathrm{ng} /$ mL TGF 2 . TGF $\beta 2$ did not affect collagen deposition by primary cells. In expanded cells, TGF 32 increased collagen deposition. Chondrocytes and fibroblasts in monolayer produced more collagen cross-links with TGF 32 . In alginate, primary and expanded cells displayed an unexpected decrease in collagen cross-linking with TGF $\beta 2$. $\alpha$ SMA was not present in alginate cultures and barely upregulated by TGF $\beta 2$. Organized aSMA fibers were present in all monolayer cultures and became more pronounced with TGF $\beta 2$. This study demonstrates that the physical environment determined by the substrate used co-determines the response of cells to TGF $\beta$. The presence of mechanical stress, determined with $\alpha$ SMA-staining, is probably responsible for the increase in collagen cross-linking upon addition of TGF $\beta$.
\end{abstract}

\section{INTRODUCTION}

T GF PLAYS AN IMPORTANT role in cartilage repair. In tissue engineering studies, TGF $\beta$ is often used to redifferentiate expanded chondrocytes. Expansion, needed to obtain sufficient cell number for tissue engineering purposes, results in dedifferentiation and a more fibroblast-like phenotype of the cells. In combination with other growth factors and in a serum-free culture medium, TGF $\beta$ induces proteoglycan production and collagen type II gene expression by expanded chondrocytes. ${ }^{1-3}$ In addition, adenoviral overexpression of TGF $\beta$ results in constitutive collagen type II expression by expanded chondrocytes. ${ }^{4}$

Next to redifferentiation of expanded chondrocytes, TGF $\beta$ is also used to induce a chondrogenic phenotype in bone marrow-derived mesenchymal stem cells resulting in the deposition of typical cartilage proteins such as aggrecan and gene expression of collagen type $\Pi^{5.6}$ Besides effects on cell phenotype, TGF $\beta$ induces production of cartilage matrix proteins. TGF $\beta$ leads to an increase in proteoglycan synthesis and content in healthy murine articular cartilage and protects against proteoglycan depletion in murine

'Department of Orthopaedics, Erasmus MC. University Medical Center Rotterdam, Rotterdam, The Netherlands.

'TNO Quality of Life, Business Unit BioSciences, Leiden, The Netherlands.

${ }^{3}$ Department of Otorhinolaryngology, Erasmus MC, University Medical Center Rotterdam, Rotterdam, The Netherlands.

'Department of Oral Cell Biology, Academic Center of Dentistry, Amsterdam, The Netherlands. 
experimental osteoarthritis (OA). ${ }^{7,8}$ Addition of TGFB to chondrocytes in culture leads to various results: stimulation of proteoglycan and collagen production, ${ }^{y-12}$ but also inhibition of proteoglycan deposition. ${ }^{13.14}$ These results indicate differential effects of TGF $\beta 1$ and TGF $\beta 2$, which most likely depend on cell type, cell source, and culture substrate, but not necessarily on the isoform. ${ }^{15}$ We have recently demonstrated that TGFB downregulates the formation of collagen pyridinoline cross-link formation by articular chondrocytes in alginate culture. ${ }^{13}$

In contrast to the positive effects of TGF $\beta$ in cartilage repair, TGF $\beta$ is also the most potent inducer of unwanted collagen gene expression by fibroblasts resulting in excessive tissue deposition and eventually fibrosis. ${ }^{16}$ Fibrosis is characterized by a high level of the pyridinoline collagen cross-links ${ }^{17}$ and the formation of these cross-links is induced by the presence of either of the three isoforms of TGF.$^{18}$ Fibrosis is also seen in vivo in articular joints where injection of TGF $\beta$ leads to fibrosis of the synovium. ${ }^{19}$ In addition, blockade of the TGF $\beta$-pathway in murine experimental $O A$ prevents against synovial fibrosis. ${ }^{8}$

Taken together, TGF $\beta$ has differential effects on cell behavior and extracellular matrix production and cross-linking. It seems that the effect is depending on cell phenotype, the physical environment determined by culture set-up, or a combination of these factors. The contribution of these factors to the differential effects of TGF $\beta$ has to be elucidated to be able to apply TGF $\beta$ to improve cartilage tissue engineering. This information will be useful for the choice of biomaterials to be used for cartilage tissue engineering. Ous goal was to compare the effect of TGF $\beta$ on collagen biochemistry and especially collagen cross-linking in different cells cultured in different physical environments. To evaluate the influence of cell phenotype, we used different cells ranging from differentiated chondrocytes to fibroblasts. To evaluate the effect of the physical environment, the cells were cultured in two different environments: attached to plastic in monolayer, where they are under continuous cellular contractile stress, or embedded in alginate gel, where they cannot adhere and thus are free from mechanical loading.

\section{EXPERIMENTAL PROCEDURES}

\section{Cell culture}

Articular cartilage was harvested from the metacarpophalangeal joints of calves aged $6-12$ months. Primary fibroblasts were obtained from split skin biopsies of the skin covering the bovine joints. To isolate chondrocytes and fibroblasts, both the full-thickness slices of noncalcified articular cartilage and the split skin biopsies were subjected to pronase ( $2 \mathrm{mg} / \mathrm{mL}$; Sigma, St. Louis, MO) digestion for $2 \mathrm{~h}$ followed by overnight collagenase B $(1.5 \mathrm{mg} / \mathrm{mL}$; Roche Diagnostics, Almere, The Netherlands) digestion. Depend- ing on the culture conditions, the primary $\mathrm{P} 0$ or expanded $\mathrm{P} 3$ cells were either resuspended in $1.2 \%(w / v)$ low viscosity alginate (Keltone, Merck, San Diego, CA) in $0.9 \% \mathrm{NaCl}$ (Sigma) at a concentration of $4 \times 10^{6}$ cells $/ \mathrm{mL}$ to make alginate beads or cultured as monolayer on plastic in a concentration of 7500 cells $/ \mathrm{cm}^{2}$. Beads were made as described previously. ${ }^{20}$ Beads were cultured in $75 \mu \mathrm{L} /$ bead and monolayers in $2 \mathrm{~mL} / \mathrm{monolayer}$ Dulbecco's modified Eagle's medium (DMEM) high glucose (GibcoBRL, Gaithersburg. MD) supplemented with $5 \%$ fetal bovine serum (Gibco$\mathrm{BRL}$ ), $50 \mu \mathrm{g} / \mathrm{mL}$ L-ascorbic acid 2-phosphate (Sigma), $50 \mu \mathrm{g} / \mathrm{mL}$ gentamicin, and $1.5 \mu \mathrm{g} / \mathrm{mL}$ fungizone (both GibcoBRL). Cells were cultured with or without $2.5 \mathrm{ng} / \mathrm{mL}$ transforming growth factor beta2 (TGFß2). TGFß1 and TGF 32 have similar effects on matrix production. ${ }^{15}$ TGF $\beta 3$ is an important factor in chondrogenic differentiation of mesenchymal stem cells and less used when primary chondrocytes are cultured. ${ }^{21.22}$ No differences were found in our previous study about the three isoforms and their effect on collagen cross-linking in fibroblast cultures. ${ }^{18}$ Therefore, TGF\%2 was chosen based on previous results. ${ }^{13}$ Culture medium was replaced three times a week.

\section{Biochemical assays}

Alginate beads or monolayers were digested overnight at $56^{\circ} \mathrm{C}$ in papain buffer $(200 \mu \mathrm{g} / \mathrm{mL}$ papain in $50 \mathrm{mM}$ ethylene diamintetraacetate (EDTA) and $5 \mathrm{mM} \mathrm{L}$-cystein). The amount of DNA in each RNAse (Sigma)-pretreated papaindigested sample was determined using ethidium bromide (GibcoBRL) dye with calf thymus DNA (Sigma) as a standard. High-performance liquid chromatography (HPLC) of amino acids (hydroxyproline, Hyp) and collagen cross-links (hydroxylysylpyridinoline, HP; lysylpyridinoline, LP) was performed by the methods of Bank er al..$^{23.24}$ The quantities of cross-links were expressed as the number of residues per collagen molecule, assuming 300 Hyp residues per collagen triple helix.

\section{Gene expression analysis}

For total RNA isolation, alginate beads were dissolved in $150 \mu \mathrm{L} /$ bead $55 \mathrm{mM}$ sodium citrate acid. Cell pellets of the alginate beads and monolayers were suspended in $1000 \mu \mathrm{L}$ RNA-Bee ${ }^{\text {TM }}$ (TEL-TEST, Friendswood, TX), and subsequently precipitated with 2-propanol and purified with lithium chloride. Total RNA was quantified using Nanodrop ${ }^{(m)}$ ND-1000 Spectrophotometer (NanoDrop Technologies, Wilmington, DE), and $500 \mathrm{ng}$ total RNA of each sample was reverse transcribed into cDNA using RevertAid ${ }^{\text {TNM }}$ First Strand cDNA Synthesis Kit (MBI Fermentas, St. Leon-Rot, Germany). For glyceraldehyde-3-phosphate dehydrogenase (GAPDH-forward: GTCAACGGATTTGGTCGTATTGGG; reverse: TGCCATGGGTGGAATCATATTGG; probe: FamTGGCGCCCCAACCAGCC-Tamra) and SRY-box containing 
gene 9 (SOX9-forward: CAACGCCGAGCTCAGCA; reverse: TCCACGAAGGGCCGC, Fam-TGGGCAAGCTCTGGAGA CTTCTGAACG-Tanra), each CDNA sample was amplified using specific primers and specific probe (Eurogentec, Seraing, Belgium). Amplifications were done as described previously. ${ }^{13}$ Data were analyzed using Sequence Detector Version 1.7 (Applied Biosystems, Foster City, CA) software and nomalized for GAPDH expression.

Immunohistochemical staining for $\alpha S M A$, type I collagen, and type II collagen

Staining for the presence and organization of $\alpha$ SMA was performed after 1 week of cuiture of primary chondrocytes and fibroblasts, to examine differences in mechanical stress between the monolayer and alginate beads. The additional effect of TGF $\beta 2$ on the organization of the $\alpha$ SMA fibers was also investigated. The presence of collagen types I and II was investigated after 4 weeks of culture. For all three stainings, three alginate beads were dissolved in $55 \mathrm{mM}$ sodium citrate acid to prepare cytospins. Cells in monolayer were cultured on glass culture chambers (BD Biosciences, San Jose, CA) to stain them immunohistochemically. Cells with surrounding pericellular matrix from alginate beads were centrifuged on glass slides and fixed in cold acetone monolayers in cold $70 \%$ ethanol. The samples were incubated with monoclonal antibodies against $\alpha$ SMA (clone number 1 A4, Sigma), type I collagen (ab6308; Abcam, Cambridge, UK), or type II collagen (1:100, II-II6B3; Developmental Studies Hybridoma Bank, Iowa City, IA) at room temperature for $1 \mathrm{~h}$. This was followed by incubation with link and label from the link-label kit (BioGenex, San Ramon, CA) for $30 \mathrm{~min}$. Freshly prepared neo-fuchsin substrate was used to achieve staining.

The collagen staining was scored for the number of cells positive for collagen types I and $I$ per 100 cells in four fields of sight per specimen, resulting in a percentage of positive cells. An arbitrary scoring system from 1 to 5 was used, with 1 representing less than $10 \%$ of the cells positive, 2 representing $10-40 \%$ positive, 3 representing $40-60 \%$ positive, 4 representing $60-90 \%$ positive, and 5 representing more than $90 \%$ of the cells positive. A cell was considered positive when the matrix around the cell or the cytoplasm was stained pink

\section{Data analyses}

The experiments were performed three times with three samples of seven beads or with three monolayers per experimental condition for biochemical analyses and one sample of 10 beads or one monolayer per experimental condition for gene expression analysis. Statistical analysis was performed using GraphPad Prism 5.0 (GraphPad Software, San Diego, CA) software. All data are presented as mean $t$ standard deviation. Control groups without TGFB2 and groups supplemented with TGF $\beta 2$ were compared with a
Kruskall-Wallis $H$-test with a post hoc Mann-Whitney $U$-test. The effect of adding TGFß2 in the alginate bead condition versus the monolayer for each cell type was compared with a two-way ANOVA with a post hoc Bonfermoni test. The relative difference between the control group (set at $100 \%$ ) and the TGF 2 group was used for these calculations

\section{RESULTS}

\section{Cell features}

The amount of DNA was determined at day 0 and after 28 days of culture to be able to compare matrix deposition between the conditions and examine the effect of the culture environment on cell proliferation. At day $0,0.12 \pm 0.03 \mu \mathrm{g}$ DNA/bead and $0.23 \mu \mathrm{g}$ DNA/monolayer was present. In all conditions," the amount of DNA increased or remained stable after 28 days of culture. This indicates that there was no cell death and even cell proliferation in most of the conditions. Overall, addition of TGF $\beta 2$ increased the total DNA amount $(p<0.005)$, although not always significantly and with exception of fibroblasts in alginate beads (Fig. 1A).

The total amount of isolated RNA was $101 \pm 11 \mathrm{ng}$ RNA per bead and 24,890 $44904 \mathrm{ng}$ RNA per monolayer. This increased with the presence of TGF $\beta 2$ in every condition $(p<0.05)$ except for the fibroblasts in beads. Here, the amount of $\mathrm{RNA}$ was not significantly changed in the presence of TGFß2.

\section{Collagen matrix deposition}

Addition of TGFP2 to the primary chondrocytes in alginate beads had no effect on collagen deposition. A low amount of collagen was depasited in cultures of dedifferentiated chondrocytes, as well as primary and dedifferentiated fibroblasts in alginate beads. Addition of TGF 32 increased the collagen deposition in $\mathrm{P} 3$ chondrocytes and fibroblasts in alginate beads $(p<0.005)$. Collagen deposition by primary chondrocytes and fibroblasts on plastic was high but not influenced by the presence of TGF 32 . Low amount of collagen was deposited in dedifferentiated P3 chondrocytes and P3 fibroblasts on plastic where addition of TGF $\beta 2$ increased collagen deposition ( $p<0.005$, Fig. 1B).

Matrices deposited by primary and expanded chondrocytes and fibroblasts in alginate beads had an average of 0.22 HP cross-links per collagen molecule. Matrices deposited by chondrocytes on plastic had a similar number of cross-links per collagen molecule in the control condition. Matrices deposited by fibroblasts on plastic had a relatively low number of HP cross-links per collagen molecule in the control condition. Addition of TGF $\beta 2$ to the culture medium resulted in a decrease of collagen cross-links in all alginate bead cultures and an increase of collagen cross-links in all cultures on plastic, independent of cell type $(p<0.001$ for alginate bead vs. plastic, Fig. 1C). 


\section{Type of collagen produced}

Chondrocytes cultured in alginate beads deposited mainly type II collagen (arbitrary score $4.25 \pm 0.5$, Fig. $2 \mathrm{~A}$ ) and less type I collagen (score of $1.5 \pm 0.6$, Fig. $2 B$ ) as determined by immunohistochemistry. Expanded chondrocytes in alginate beads had a trend toward more type I collagen than primary chondrocytes (score of $2 \pm 0.5$, not significant). However, after 28 days, type $I$ collagen was the main type of collagen deposited (score $3.25 \pm 1, p<0.05$ vs. collagen type I production) by the expanded chondrocytes as well. The primary and expanded fibroblasts in beads deposited almost no type II collagen and more type I collagen than the chondrocytes. Addition of TGF 32 only increased the type II collagen deposition (score of $3.75 \pm 0.5, p<0.05$ vs. control without $\Upsilon \mathrm{GF} \beta 2$ ) in the expanded chondrocytes, and no effect of TGF $\beta$ was seen in the other alginate bead conditions. Chondrocytes cultured on plastic deposited very little type II collagen (score $1.5 \pm 0.6$ ) and more type I collagen (score $3.75 \pm 0.5$ ) than the chondrocytes cultured in alginate beads. Dedifferentiated chondrocytes and both primary as well as expanded fibrablast deposited only type I collagen (score $4.75 \pm 0.5$, Fig. 2C) and almost no type II collagen (score $0.5 \pm 0.6$, Fig. 2D). After TGF $\beta$ addition, a trend toward more type II collagen was present in the primary chondrocytes on plastic $(1.25 \pm 0.5$, not significant). No effect of TGF $\beta$ was seen in the other conditions.

\section{Phenotype of the cells}

After culture for 28 days, the gene expression for SOX9 was examined to provide an indication of the phenotype of the cells. $\$ O X 9$ gene expression was the highest in primary chondrocytes cultured in alginate beads ( $\mathrm{PO}$ chondro beads). Chondrocytes cultured for three passages and subsequently in alginate beads ( $\mathrm{P} 3$ chondro beads) and the primary chondrocytes cultured on plastic (PO chondro monolayer) also expressed some $50 \times 9$, but not as much as the primary chondrocytes in alginate beads. The passage 3 chon. drocytes on plastic and all the fibroblast conditions almost did not express the $S O X 9$ gene (Fig. 3). Addition of TGFß2 reduced $S O X 9$ expression in the alginate bead and monolayer cultures of primary chondrocytes $(p<0.005)$ but increased it in the expanded chondrocytes in alginate beads $(p<0.005)$.

\section{aSMA organization}

In alginate beads, none of the chondrocytes had detectable aSMA, but some fibroblasts were positive for $\alpha$ SMA (Fig. $4 \mathrm{~A}$ and $\mathrm{C}$ ). In monolayer culture, positive $\alpha S M A$ staining without specific stress fibers was detectable in the majority of the chondrocytes (Fig. 4E). All fibroblasts were positive for $\alpha$ SMA as shown with a red staining, although also no clear stress fibers were visible (Fig. 4G). Addition of TGFB2

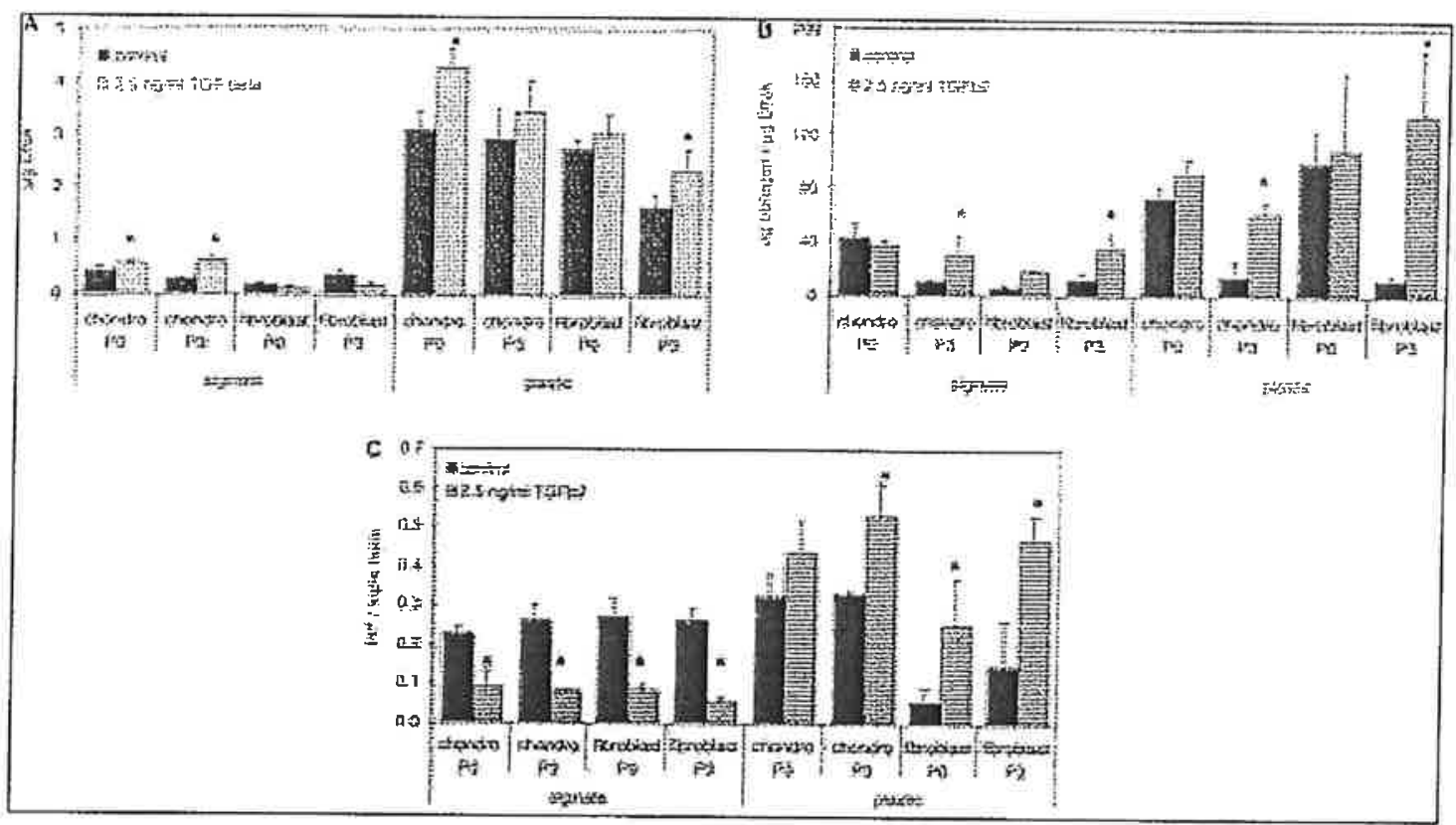

FIG. 1. Effect of $2.5 \mathrm{ng} / \mathrm{mL}$ TGFB2 on (A) DNA content, (B) collagen deposition, and (C) number of collagen cross-links in cultures of primary (P0) and expanded (P3) chondrocytes and fibroblasts cultured in alginate beads or as monoiayer on plastic for 28 days $(n=0)$. Asterisk $\left(^{*}\right)$ indicates significant difference $(p<0.005)$ from control without TGF $\beta 2$. Data are shown as mean \pm SD. 


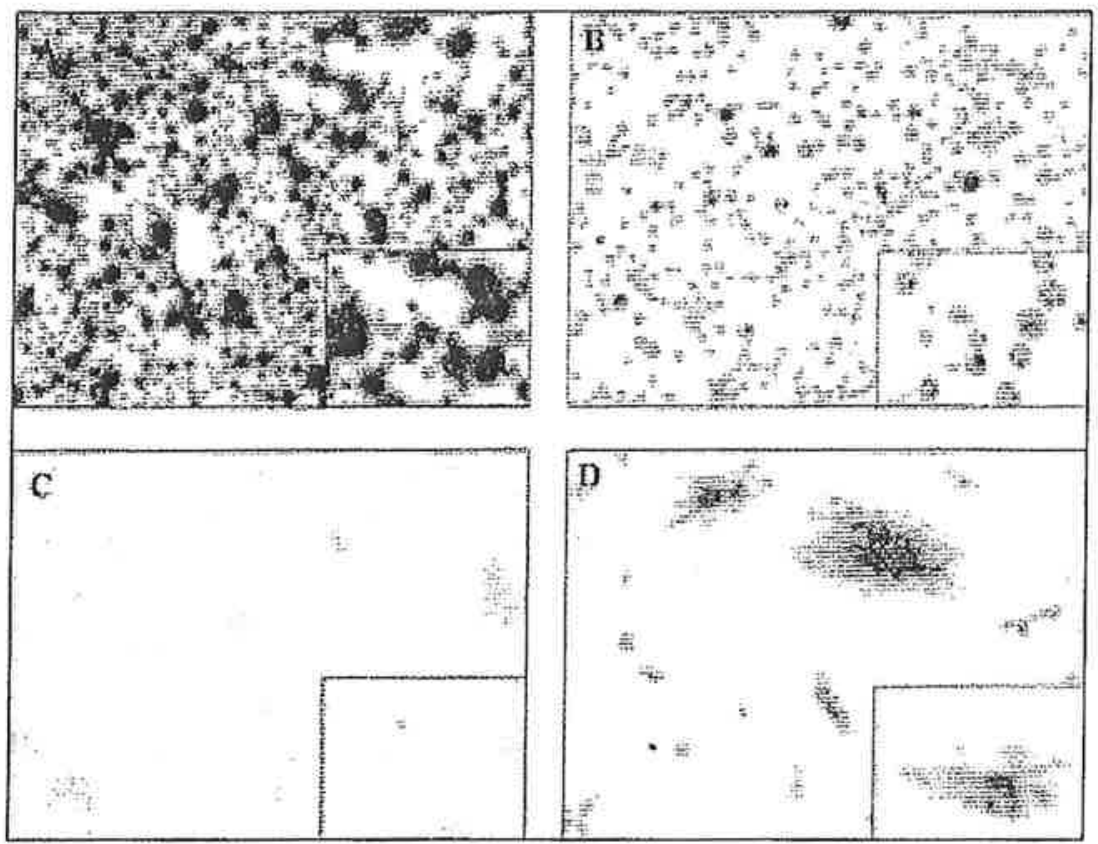

FIG. 2. Immunohistochemical staining for collagen type II (A, C) and coilagen type I (B, D) of chondrocytes cultured for 28 days in alginate beads ( $A$ and $B$, here shown as cells with pericellular matrix on glass slides) and as monolayer on plastic ( $C, D$ ). Positive cells are shown in red. Magnification is $100 x$. Color images available online at www.liebertpub.com/ten.

to chondrocytes and fibroblasts in alginate beads resulted in more $\alpha$ SMA and the intensity of staining was higher. However, no intracellular stress fibers of $\alpha S M A$ were visible (Fig. 4B and D). When the cells (chondrocytes and fibroblasts) were cultured on plastic, the presence of TGF $\beta 2$ induced $\alpha$ SMA with clearly visible organized stress fibers in all the cells as shown in Figure $4 \mathrm{~F}$ and $\mathrm{H}$.

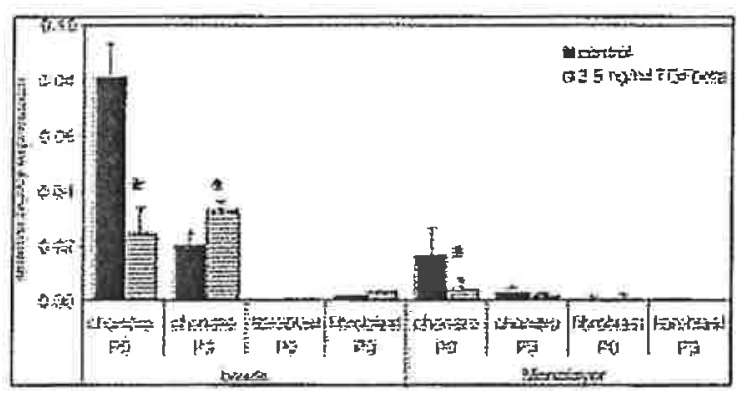

FIG. 3. Relative gene expression of $S O X Q$ by primary $(\mathrm{PO})$ and expanded (P3) chondrocytes and fibroblasts cultured in alginate beads or in monolayer on plastic for 28 days $(n=6)$. The gene expression analysis was used to determine the phenotype of the cells after culture. Asterisk $\left(^{*}\right)$ indicates significant difference $(p<$ 0.005 ) from control without TGF32. Data are shown as relative expression $\pm \mathrm{SD}$.

\section{DISCUSSION}

This study demonstrates that the effect of TGF $\beta$ on crosslinking of collagen is mostly determined by the physical environment determined by the culture substrate of the cells and less by the cell phenotype or the type of collagen produced. When chondrocytes are cultured in alginate beads, TGFB2 leads to less collagen cross-links in the deposited matrix. In the monolayers on plastic on the other hand, addition of TGF 32 leads to more collagen cross-links in the deposited matrix.

The results elucidate the discrepancy in our previous results. A study with skin fibroblast cultured on plastic showed that TGF $\beta$ increased collagen cross-link formation. ${ }^{18}$ However, in a study with differentiated chondrocytes in alginate gel, we surprisingly found an inkibition of collagen crosslink formation by TGF $\beta .^{13}$ These studies differed in cell type used as well as physical environment used. In the present study eight different combinations of cell type and physical environment were compared to evaluate what determines the effect of TGF $\beta$ on collagen cross-link formation.

One of the main physical differences between plastic and alginate culture is the contractile stress on the cell. The culture systems used were investigated for their effect on the contractile stress on chondrocytes and fibroblasts by staining the cells for the presence and organization of aSMA. It has previously been shown that when the culture 


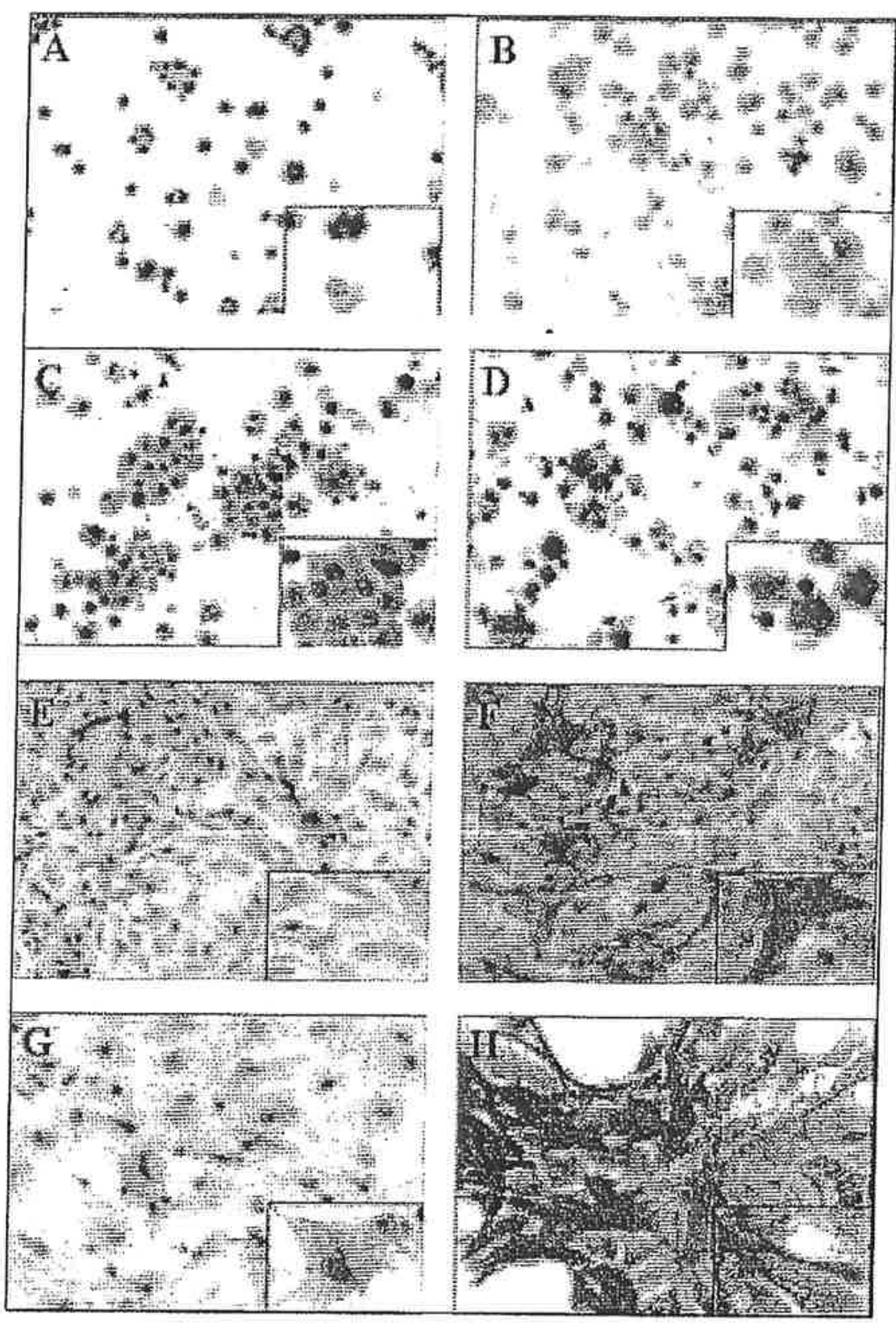

FIG. 4. Immunohistochemical staining for $\alpha$-smooth muscle actin $(\alpha S M A)$ of primary P0 chondrocytes $(A, B, E, F)$ and fibroblasts (C, D, G, H) cultured in alginate beads (A-D, here shown as cells with pericellular matrix on glass slide) or in monolayer on plastic $(\mathrm{E}-\mathrm{H})$ for 28 days. $\alpha$ SMA shown in red is upregulated in response to TGFß2 $(\mathbf{B}, \mathbf{D}, \mathbf{F}, \mathbf{H})$ although not organized in spindles in the cells cultured in alginate beads (B, D). Cells cultured in monolinyer in the presence of TGF $\beta 2$ have organized $\alpha$ SMA fibers (F, H). Magnification is $200 \times$ with a $1000 \times$ inset. Color images available online at www.liebertpub.com/ten.

substrate exerts force on a cell, more $\alpha$ SMA is present in the cell. ${ }^{25-27}$ Inhibition of $\alpha$ SMA assembly reduces contraction of a collagen-glycosaminoglycan scaffold, indicating the importance of $\alpha$ SMA in the interaction between the cell and its environment. ${ }^{28}$ This corresponds to our findings where ๙SMA is absent or poorly organized in the cells cultured in alginate beads, but clearly present in attaching cells cultured on plastic. It also confirms that cells cultured on plastic are 
under continuous contractile stress as a result of anchorage to the substrate and cell-cell contact. Cells cultured in alginate beads do not experience this stress because of less or no cell-cell contact and the absence of anchorage to the culture substrate. In the culture systems we used, especially the monolayer on plastic, it is difficult to uncouple cell-cell contact and anchorage to the culture substrate and their effect on the organization of $\alpha$ SMA. The effect of other differences between alginate and plastic, like for instance differences in nutrient diffusion or cell viability, cannot be completely excluded. Considering the cell viability, the amount of DNA did not decrease from days 0 to 28 for any alginate condition. Together with the presence of RNA after 28 days of culture, this indicates the absence of cell death also in the fibroblasts cultured in alginate beads. We therefore believe that the effect seen in the alginate beads depends on the culture environment and not on cell viability and therefore a selection in the type of collagen deposited or phenotype. We can conclude that the culture environment greatly influences the effect of TGFB on the collagen matrix.

To study the relation with cell phenotype, we determined gene expression for $S O X 9$ and immunohistochemical staining for collagen types I and II. SOX9 gene expression and the type of collagen deposited are related to the phenotype of the cells but not to the effect of TGF $\beta$ on collagen cross-linking: in case of the alginate bead cultures, no collagen type II was present in the fibroblast cultures. Here, addition of TGF $\beta$ decreased the number of collagen cross-links. Collagen type II was also present in the PO chondrocytes cultured on plastic. The deposition of collagen type II increased slightly together with an increase in collagen cross-links with the presence of TGF $\beta$. On the other hand, our data indicate that the cellular contractile stress on the cells, as determined by $\alpha S M A$ production and organization, is related to the effect of TGFB. We conclude from these data that the effect of TGF $\beta$ on collagen cross-linking is dependent on the physical environment of the cells. It was recently found that $\alpha$ SMA is a meclianosensitive protein that is recruited to stress fibers under bigh tension. This recruitment allows cells to exert more stress on the culture scaffold, ${ }^{29}$ TGFB further upregulates $\alpha S M A$ deposition and condensation. Previously, it was found that TGF $\beta$ induces $\alpha$ SMA in fibroblasts. ${ }^{30.31}$ More recently, it is also seen in chondrocytes, ${ }^{28,32}$ which corresponds with our findings, that cells incubated with TGF $\beta$ have more $\alpha$ SMA staining. We hypothesis that in conditions of high tensile stress on the cell, the presence of TGF $\beta$ further increases $\alpha$ SMA organization and leads to collagen cross-link formation to better resist the stress. Moreover, addition of TGF $\beta$ does not inevitably has to result in fibrosis. If tensile stress is prevented, TGF $\beta$ can be used to increase collagen and proteoglycan production without leading to fibrosis. Therefore, the intended effect of TGF $B$ in cartilage repair will depend on environmental conditions, such as mechanical environment and the scaffold used. Because collagen cross-linking has important implications on mecharical properties of the repair tissue, this should be seriously considered when choosing a scaffold in tissue engineering procedures where TGF $\beta$ is often used to stimulate tissue formation.

\section{ACKNOWLEDGMENTS}

The monoclonal antibody $\amalg-116 \mathrm{~B} 3$ against collagen type II developed by Rikard Holmdahl and Kristofer Rubin was obtained from the Developmental Studies Hybridoma Bank developed under the auspices of the NICHD and maintained by Department of Biological Sciences. The University of Iowa, Iowa City, IA.

Supported by a grant of The Dutch Arthritis Association (Reumafonds), NR 02-2-40.

\section{REFERENCES}

1. Barbero, A., Ploegert, S., Heberer, M., and Martin, I. Plasticity of clonal populations of dedifferentiated adult human articular chondrocytes. Arthritis Rheum 48(5), 1315, 2003.

2. Mandl, E.W., van der Veen, S.W., Verhaar, J.A., and yan Osch, G.J. Serum-free medium supplemented with highconcentration FGF2 for cell expansion culture of human ear chondrocytes promotes redifferentiation capacity. Tissue Eng $8(4), 573,2002$.

3. van Osch, G.J., van der Veen, S.W., and Verwoerd-Verhoef, H.L. In virro redifferentiation of culture-expanded rabbit and human auricular chondrocytes for cartilage reconstruction. Plast Reconstr Surg 107(2), 433, 2001

4. Lee, D.K., Choi, K.B., Oh, I.S., Song, S.U., Hwang, S., Lim, C.L., Hyun, J.P., Lee, H.Y., Chi, G.F., Yi, Y., Yip, V, Kim, J., Lee, E.B., Noh, M.J., and Lee, K.H. Continuous transforming growth factor betal secretion by cell-mediated gene therapy maintains chondrocyte redifferentiation. Tissue Eng $11(1-2), 310,2005$.

5. Barry, F., Boynton, R.E., Liu, B., and Murphy, J.M. Chondrogenic differentiation of mesenchymal stem cells from bone marrow: differentiation-dependent gene expression of matrix components. Exp Cell Res 268(2), 189, 2001.

6. Cassiede, P., Dennis, J.E., Ma, F., and Caplan, A.I. Osteochondrogenic potential of marrow mesenchymal progenitor cells exposed to TGF-beta 1 or PDGF-BB as assayed in vivo and in virro. J Bone Miner Res 11(9), 1264, 1996

7. Scharstuhl, A., Glansbeek, H.L., van Beuningen, H.M., Vítters, E.L., van der Kraan, P.M., and van den Berg, W.B. Inhibition of endogenous TGF-beta during experimental osteoarthritis prevents ostcophyte formation and impairs cartilage repair. J Iramunol 169(1), 507, 2002.

8. Scharstuhl, A., Diepens, R., Lensen, J., Vitters, E., van Beuningen, H., van der Kraan, P., and van den Berg, W.B. Adenoviral overexpression of Smad-7 and Smad-6 differentially regulates TGF-beta-mediated chondrocyte proliferation and proteoglycan synthesis. Osteoarthritis Cartilage 11(11), 773,2003

9. Galera, P., Vivien, D., Pronost, S., Bonaventure, J., Redini, F., Loyau, G., and Pujol, J.P. Transforming growth factor-beta 1 (TGE-beta 1) up-regulation of collagen type II in primary 
cultures of rabbit articular chondrocytes (RAC) involves increased mRNA levels without affecting mRNA stability and procollagen processing. I Cell Physiol 153(3), 596, 1992.

10. Redini, F., Galera, P., Mauviel, A., Loyau, G., and Pujol, J.P. Transforming growth factor beta stimulates collagen and glycosaminoglycan biosynthesis in cultured rabbit articular chondrocytes. FEBS Lell 234(1), 172, 1988.

11. van Osch, G.J., van den Berg, W.B., Hunziker, E.B., and Hauselmann, H.J. Differential effects of IGF-1 and TGF beta-2 on the assembly of proteoglycans in pericellular and territorial matrix by cultured bovine articular chondrocytes. Osteoarthritis Cartilage 6(3), 187, 1998.

12. van Osch, G.J., van der Veen, S.W, Buma, P., and VerwoerdVerhoef, H.L. Effect of transforming growth factor-beta on proteoglycan synthesis by chondrocytes in relation to differentiation stage and the presence of pericellular matrix. Matrix Biol 17(6), 413, 1998.

13. Jenniskens, Y.M., Koevoet, W., de Bart, A.C., Weinans, H. Jahr, H., Verhaar, J.A., DeGroot, J., and van Osch, G.J.V.M. Biochemical and functional modulation of the cartilage collagen network by IGF1, TGFbeta2 and FGF2. Osteoarthritis Cartilage 14(11), 1136, 2006.

14. van Susante, J.L., Buma, P., van Beuningen, H.M., van den Berg, W.B., and Veth, R.P. Responsiveness of bovine chondrocytes to growth factors in medium with different serum concentrations. J Orthop Res 18(1), 68, 2000.

15. Morales, T.I., Joyce, M.E., Sobel, M.E., Danielpour, D., and Roberts, A.B. Transforming growth factor-beta in calf articular cartilage organ cultures: synthesis and distribution. Arch Biochem Biophys 288(2), 397, 1991.

16. Jimenez, S.A., Hitraye E, and Varga, J. Pathogenesis of scleroderma: collagen. Rheum Dis Clin North Am 22(4), 647, 1996.

17. van der Slot, A.J., Zuurmond, A.M., van den Bogaerdt, A.J., Ulich, M.M., Middelkoop, E., Boers, W., Ronday, KH., DeGroot, J., Huizinga, T.W., and Bank, R.A. Increased formation of pyridinoline crass-links due to higher telopeptide lysyl hydroxylase levels is a general fibrotic phenomenon. Matrix Biol 23(4), 251, 2004.

18. van der Slot, A.J., van Dura, E.A., de Wit, E.C., De Groot, J., Huizinga, T.W., Bank, R.A., and Zewrnond, A.M. Elevated formation of pyridinoline cross-links by profibrotic cytokines is associated with enhanced lysyl hydroxylase 26 levels. Biochim Biophys Acta 1741(1-2), 95, 2005.

19. Allen, J.B., Manthey, C.L., Hand, A.R., Ohura, K., Ellingsworth, L., and Wah, S.M. Rapid onset synovial inflammation and hyperplasia induced by transforming growth factor beta. J Exp Med 171(1), 231, 1990.

20. Hauselmann, H.J., Aydelotte, M.B., Schumacher, B.L., Kuettoer, K.E., Gitelis, S.H., and Thonar, E.J, Synthesis and turnover of proteoglycans by human and bovine adult articular chondrocytes cultured in alginate beads. Matrix 12(2), $116,1992$.

21. Haider, M., Cappello, J., Ghandehari, H., and Leong, K.W. In vitro chondrogenesis of mesenchymal stem cells in recombinant silk-elastinjike hydrogels. Pham Res 25(3), 692, 2008.

22. Neumann, K. Endres, M., Ringe, J., Flath, B., Manz, R., Haupl, T., Situinger, M., and Kaps, C. BMP7 promotes adipogenic but not osteo-/chondrogenic differentiation of adult human bone marrow-derived stem cells in high-density micro-mass culture. J Cell Biochem 102(3), 626, 2007.

23. Bank, R.A., Jansen, E.J., Beeknan, B., and te Koppele, J.M Amino acid andysis by reverse-phase high-performance liquid chromatography: improved derivatization and detection condítions with 9-fluorenylmethyl chloroformate. Anal Biochem 240(2), 167, 1996.

24. Bank, R.A., Soudry, M., Maroudas, A., Mizrahi, J., and TeKoppele, J.M. The increased swelling and instantaneous deformation of osteoarthritic cartilage is highly correlated with collagen degradation. Arthritis Rheum 43(10), 2202, 2000.

25. Arora, P.D., Narani, N., and McCulloch, C.A. The compliance of collagen gels regulates transfoming growth factorbela induction of alpha-sinooth muscle actin in fibroblasts. Am J Pathol 154(3), 871, 1999.

26. Hinz, B., Mastrangelo, D., Iselin, C.E., Chaponnier, C., and Gabbiani, G. Mechanical tension controls granulation tissue contractile activity and myofibroblast differentiation. Am J Pathol 159(3), 1009, 2001.

27. Zaleskas, J.M, Kinner, B., Freyman, T.M., Yannas, I.V., Gibson, L.J., and Spector, M. Contractile forces generated by articular chondrocytes in collagen-glycosaminoglycan matrices. Biomaterials 25(78), 1299, 2004.

28. Zaleskas, J.M., Kinner, B., Freyman, T.M., Yannas, I.V. Gibson, L.J., and Spector, M. Growth factor regulation of smooth muscle actin expression and contraction of humar articular chondrocytes and menjscal cells in a collagen-GAG matrix. Exp Cell Res 270(1), 21, 2001.

29. Goffin. J.M., Pittet, P., Csucs, G., Lussi, J.W., Meister, J.J., and Hinz, B. Focal adhesion size controls tension-dependent recruitment of alpha-smooth muscle actin to stress fibers. J Cell Biol 172(2), 259, 2006.

30. Desmouliere, A., Geinoz, A., Gabbiani, F, and Gabbiari, G. Transforming growth factor-beta I induces alpha-smooth muscle actin expression in granulation tissue myofibroblasts and in quiescent and growing culnred fibroblasts. J Cell Biol 122(1), 103, 1993.

31. Romov-Jessen, L., and Petersen, O.W. Induction of alphasmooth muscle actin by transforming growth factor-beta 1 in quiescent human breast gland fibroblasts. Implications for myofibroblast generation in breast neoplasia. Lab Invest 68(6), 696, 1993

32. Kinner B., and Spector M. Smooth muscle actin expression by human articular chondrocytes and their contraction of a collagen-glycosaminoglycan matrix in vitro. J Orthop Res $19(2), 233,2001$.

Address reprint requests to: Gerjo J.V.M. van Osch, Ph.D.

Departments of Orthopaedics and Otorhinolaryngology Erasmus $M C$

University Medical Center Rolterdam P.O. Box 2040 3000 CA Rotterdam The Netherlands

E-mail: g.vanosch@erasmusmc.nl 